\title{
Protection To The Victims of Domestic Violence Crime (Case Study In Kudus Police)
}

\author{
Cipto $^{1}$
}

Abstract. Family violence or who is often called it with domestic violence is a universal problem faced by a country. This research to know and analys the application of the law and protection to victims of criminal acts of domestic violence, as well as the barriers and solutions in the protection of victims of domestic violence

This research using empirical juridical approach or commonly referred to as the Juridical Sociological. The research is specified as descriptive analytical research.

The results of this study are (1) a form of protection of domestic violence victims temporary and permanent protection of the court less attention. (2) Barriers in Implementing Law Enforcement Protection of Victims of Domestic Violence, namely: a. Domestic violence is often not reported to the police, because the victims felt shame; $b$. If the case had no complaints are often the victim withdraws the complaint and intends to settle the case in family. The conclution in this research that the legal protection for victims of domestic violence according to Act No. 23 of 2004 on the Elimination of Violence in the household is necessary. Obstacles of domestic violence is often not reported to the police. If the case has a complaint often the victims withdraw their complaint and intend to settle cases in a family manner.

Keywords: Legal Protection; Victims of Domestic Violence.

\section{Introduction}

Means of protection of citizens can be achieved with law enforcement. The mandate of the Constitution of the Republic of Indonesia in Article 1 (3) that Indonesia is a State of Law. Thereby supreme law is the rule of the Republic of Indonesia to protect all the peoples of Indonesia.

According Sudikno Mertokususmo legal norms aimed primarily at concrete perpetrators, namely the perpetrators of violations that obviously do, not to enhance the human, but to order an orderly society, in order not to fall victim of the crime, in order to prevent crime ${ }^{2}$. Legal reforms, particularly in criminal law that the foreign literature the term "politics of criminal law" is often known by the term "penal policy", "criminal law policy" or "Strafrecht politiek. ${ }^{3}$

Indonesian Penal Code in force at the moment is the Criminal Code that comes from the Dutch colonial law (Weatboek van Staftrecht) which practically is not in accordance with the conditions of Indonesian society nowadays. In fact this which causes the need

\footnotetext{
${ }^{1}$ Student of Master of Law, Universitas Islam Sultan Agung Semarang and Members of the Indonesian National Police (Polri), Email: ciptopanji@yahoo.com

${ }^{2}$ Sudikno Mertokusumo, Mengenal Hukum, Liberty, Yogyakarta, , 2003, p. 12

${ }^{3}$ Barda Nawawi Arief, Bunga Rampai Kebijakan Hukum Pidana, Prenada Media Group, Jakarta, 2008, p. 26.
} 
to reform the criminal law (penal reform) on Indonesia. The necessary to reform criminal law in line with the results of the 1976 United Nations Congress on the prevention of crime and treatment of offenders ${ }^{4}$.

Renewal today regarding the completion of the criminal law starts from criminal cases involving minors as the mandate of Act No. 11 of 2012 on the Criminal Justice System of Children and Women within the domestic sphere in the case of domestic violence settlement of the case was not to end up in court. This is a new paradigm in the form of settlement in the case of domestic violence. In the law that is normally within the scope of family violence investigator in the Indonesian National Police (Polri) in the case of law enforcement already familiarize yourself with the approach of restorative justice or restorative justice is a form of rehabilitation of victims and perpetrators.

In domestic violence that usually become victims of domestic violence who is the wife as the female figure in family. The rehabilitation perpetrators and victims that focuses on wound healing (to restore) suffered by the victim and not motivated by revenge (an eye for an eye $)^{5}$. Violence in the household is or who is often called domestic violence is a universal problem faced by a state. The causes of the domestic violence happens in all walks of life does not distinguish status of society. Many layer of non-governmental organization (NGO) Women raise this issue to promote and protect women's interests. The struggle of the women's movement resulted in the establishment of the National Commission on Violence or better known as Woman Right Commission/"Komnas Perempuan", it encourages stakeholders with the enactment of Act No. 23 of 2004 on the Elimination of Domestic Violence. ${ }^{6}$

Protection of victims requires a study which indept to know the causes of the criminal acts of violence to women, in prevention efforts undertaken by the government and society and what obstacles are faced by law enforcement agencies in implementing legislation that provides protection to victim female criminal acts of violence in the home stairs.

The problem of this research is the application of the legal protection of crime victims of domestic violence. Obstacles and solutions in the protection of crime victims of domestic violence.

The goal of research is to know and analyze the law enforcement protection of victims of criminal acts of domestic violence. Identify and analyze the barriers and solutions in the protection of crime victims of domestic violence.

\section{Research methods}

\footnotetext{
${ }^{4}$ Mudzakir, Perencanaan Pembangunan Hukum Nasional Bidang Politik Hukum Pidana Dan Sistem Pemidanaan, Badan Pembinaan Hukum Nasional Kementrian Hukum Dan HAM Republik Indonesia, Jakarta, 2012, p.57

${ }^{5}$ Fatahillah A.Syukur, 2011, Mediasi Perkara KDRT teori dan Praktek Di Pengadilan Indonesia, Mandar Maju, Bandung, Bandung, p. 10

${ }^{6}$ lbid., p.5
} 
This research is legal using empirical juridical approach or commonly referred to as the Juridical Sosiological used analyze qualitatively about the protection of crime victims of domestic violence. ${ }^{7}$ The data collection can be performed using primary sources and secondary. Primary data obtained is the first source by which a generated data ${ }^{8}$. And secondary sources are sources that do not directly provide the data on the data collection.

Methods of data analysis used in this research is descriptive and qualitative analysis, which is a way of analysis of the results of research that produce descriptive data analytical, that the data stated by the respondent in writing or orally as well as the behavior of the real, which is researched and studied as a whole. ${ }^{9}$

\section{Results and Discussion}

\subsection{Application of the Law for the Protection of Victims of Crime of Domestic Violence}

Protection of victims of domestic violence at the preventive stage is done through temporary refuge and protection by the courts, as well as advocates of victims of domestic violence. Legal protection for the wife who become victims of domestic violence under this law are: (1) temporary protection; (2) the establishment of a protective order by the court; (3) provision of Special Service Room (RPK) at a police station; (4) provision of safe homes or alternative housing; (5) provision of legal advice by lawyers for victims at the level of investigation, prosecution and examination at trial. $^{10}$

Given that most law enforcement officers are men, therefore as mandated by this legislation provided a special institution, the RPK in the police institution with a special officer similarly, policewoman, so that the victims are not afraid to report mistreatment. During this time many victims of domestic violence who can not get out of the cycle of violence due to the reluctance or fear of the victim reported to the law enforcement authorities. One cause of fear or unwillingness of the victim is the attitude of the police who tend interrogative, impressed not protect victims, even if it blame the victim. In some victims report cases of domestic violence are less responded seriously by the police.

In providing temporary protection, the police can cooperate with health workers, social workers, volunteer, and or spiritual director to assist victims (Article 17 of Act

\footnotetext{
${ }^{7}$ Mukti Fajar ND dan Yulianto Achmad, Dualisme Penelitian Hukum Normatif \& Empiris, Pustaka Pelajar, Yogyakarta, 2010, p.47

${ }^{8}$ Burhan Bungin, 2001. Metode Penelitian Sosial, Format-format Kuantitatif dan kualitatif.: Airlangga Unversity Press, Surabaya, p. 129

${ }^{9}$ Ibid, p.192.

${ }^{10}$ Suryono Ekotama, ST. Harum Pudjianto, and G.Wiratana, Abortus Provocatus Bagi Korban Pemerkosaan Perspektif Viktimologi, Kriminologi dan Hukum Pidana Ed. I; Universitas Atmajaya, Yogyakarta: 2001, p. 176-177
} 
No. 23 of 2004). In addition, the police are required to provide information to victims about the rights of victims to services and assistance (Article 18 of Act No. 23 of 2004). Police also immediately delivered to the victim about: the identity of the officer for an introduction to victims of domestic violence as a crime against human dignity, and the police obligation to protect the victim (Article 20 of Act No. 23 of 2004). ${ }^{11}$

Given the negative impact suffered by victims can be psychic, thus requiring psychological care or treatment of the victim psikiater. In ahonther side also need counseling. In this regard, according to Article 22 of this law, a social worker who will provide services to victims are required to; a). Conduct counseling to strengthen and provide security for the victim, b). Giving information regarding the rights of victims to get protection from the police and the establishment of a protective order from the court, c). Companied victim to a safe house or alternative housing, d). Conduct integrated coordination in providing services to victims with the police, social services, social institutions needed by the victim. ${ }^{12}$

The provisions of Article 22 of this Act substantially respond to and accommodate the needs of wives who are victims of domestic violence are not only a form of protection of a physical nature, but he is also in desperate need of protection that are nonphysical, namely security from acts of domestic violence of husband against her. Giving a sense of security here is done after the occurrence of violence against victim. So, is more psychological recovery of victims.

Based on interviews with detectives Adj of Kudus Police, AKP Ongkoeseno G Sukahar, that is now a law or laws governing domestic violence, namely Act No. 23 of 2004 on the Elimination of Domestic Violence (PKDRT Law). Criminal provisions for perpetrators of domestic violence under Article 44 to Article 50 of the Law on Elimination of Domestic Violence. ${ }^{13}$

This is in line with the statement of Brigadier Hadi Sutikno, as Assistant Police Investigator of Kudus that:

"The presence of law enforcement of PKDRT very helpful in cases of domestic violence experienced by victims of domestic violence so that perpetrators of domestic violence be punished for the violence that has been done. For physical violence offenders charged with Article 44, the abuser psychic charged with Article 45, sexually violent offenders charged with Article 46 and perpetrators of family abandonment charged with Article 49. "14

Based on observations conducted by researchers that in cases of domestic violence is the perpetrator of domestic violence have been detained investigators conduct investigations against perpetrators (Anton Setiyo bin Sabari) and the victim (Nur Laili Mugfiroh). That the result of violence perpetrated by Anton Setiyo Bin Sabari make the

\footnotetext{
${ }^{11}$ Act No. 23 of 2004, concerning the Elimination of Domestic Violence, p. 7-8.

${ }^{12}$ Ibid., p. 8-9.

${ }^{13}$ Interview with AKP Ongkoeseno G Sukahar Investigation Police of Kudus, Adj Police Investigation, dated December 5, 2018

${ }^{14}$ Interview with Brigadier Hadi Sutikno Kudus Police as investigators maid, dated December 5, 2018
} 
witness could not work for three (3) days, but during the seven (7) days of the witness is still sore but the witness forced to work and when witness using the mask as a witness embarrassed with friends witness and to now 1 (one) month still red eye witness. The action on the suspect Anton Setiyo bin Sabari reasonably suspected of violating the formulation of Article 44 Paragraph (1) or paragraph (2) of Act No. 23 of 2004 on the Elimination of domestic violence.

\subsection{Obstacles and Solutions in the Protection of Victims of Crime of Domestic Violence.}

Obstacles in the handling of domestic violence begins at the time of investigation. Investigator Police (Polri) face constraints because of the strong public perception that domestic violence is a private matter or a household problem, so it is not worth interfered by other people or the police. Woman (wife) because it has a soft feeling of conscience and the strong custom and culture of the East, became the heart to reward the husband or ex-husband with his actions to the police report, although it has been hurt and abused her both physically and psychologically.

This was confirmed through interviews with Brigadier Hadi Sutikno who said that currently there is a report that comes in the police immediately briefed the victims, then an investigation. For its own protection for victims of domestic violence do if the victim asked. ${ }^{15}$

Furthermore, Brigadier Hadi Sutikno also states that every investigator in the Unit PPA Kudus Police handling of domestic violence cases are in accordance with the PKDRT Law. We have been trying to notify victims about their rights as victims, then conduct investigations, gather evidence and if the victim is afraid of threats from the perpetrators, then we will arrest and detention for offenders as one of the duties of the police to protect victims. ${ }^{16}$

Furthermore, Nur Laili Mugfiroh, as victims of domestic violence who said, "If my husband was not arrested. Because, I do not ask for protection to police. So when I have reported to the police, I fled to my parents' house. "17

In general, the phenomenon of domestic violence cases has its own specifications, are as follows:

- Outbreaks of violence more widely known by the perpetrator and the victim, so that lack of witnesses or other evidence which comply with Article 183 and 184 Criminal Procedure Code;

- The victim does not want to report the case because it was taboo and considered would open his own family disgrace, especially for cases involving sexual abuse;

\footnotetext{
${ }^{15}$ Ibid.

${ }^{16}$ Ibid.

${ }^{17}$ Interview with Nur Laili Mugfiroh as victims, dated December 5, 2018
} 
- For victims who want to report and the case is eligible formal and substantive, not infrequently tried to pull back because they feel he is in need of a future for his children and his household still wants to be rebuilt;

- Delay reports of casualties on the occurrence of cases of domestic violence will affect the level of difficulty of the investigator to conduct the investigation, particularly the collection of witness evidence. ${ }^{18}$

Act No. 23 of 2004 on the Elimination of Domestic Violence, Article 51: physical violence crime referred to in Article 44 paragraph (4) is complaint-based offense. Article 52: The psychic violence crime referred to in Article 45 paragraph (2) shall constitute offense aduan.Pasal 53: sexual violence crime referred to in Article 46 committed by a husband against his wife or vice versa is a complaint-based offense.. Some of the solutions to overcome the above:

- Establishing Space and Special Services (RPK), as the case- handling of domestic violence and abuse of children;

- Forming units for women and children (PPA) of up to Police Headquarters level, as outlined in the Police Regulation No. 10 of 2007;

- Increasing the number of policewomen in order to approach the ideal ratio. Hopes, policewomen will be gardaterdepan in handling cases of child protection and domestic violence;

- Organizing seminars / workshops aimed to provide information about the provisions / regulations related to the issue of legal protection of children and domestic violence

- Establish cooperation with the Ministry of Women's Empowerment compile a manual or pocket book grip of police in handling domestic violence cases.

\section{Closing}

\subsection{Conclution}

- Legal protection of victims of domestic violence according to Act No. 23 of 2004 on the Elimination of Domestic violence is needed for all forms of violence, especially domestic violence, is a violation of human rights and crimes against human dignity and a form of discrimination.

- Obstacles in Implementing Law Enforcement Protection of Victims of Domestic Violence, namely:

- Domestic violence is often not reported to the police, because victim felt ashamed to open a household problem to another party;

- If the case had no complaints are often the victim withdraws the complaint and intends to settle the case amicably;

\footnotetext{
${ }^{18}$ https://elisatris.wordpress.com/Peran Polri Dalam Perlindungan Anak Dan Penanggulangan Kekerasan Dalam Rumah Tangga. Accessed at 11 Nopember 2018.
} 
- Handling cases of domestic violence has not been run in accordance with laws and regulations due process in the case investigation is going well before police.

\subsection{Suggestion}

Suggestions in this study are as follows:

- Government and local government as stipulated in Act No. 23 of 2004 on the Elimination of Domestic Violence, need to improve infrastructure in the handling of victims of domestic violence who need health recovery both physically and psychologically, because health care is done in a health facility owned government, local government, or the public. Similarly, the increase in the number and quality of health worker in accordance with professional standards need to be improved.

- Implementation of the rule of law in the settlement of domestic violence require collaboration between government and society to disseminate law enforcement domestic violence, so there is an increasing awareness of the law for the victim to denounce the events of domestic violence to be processed in accordance with judicial procedures apply.

\section{Bibliography}

\section{Book}

[1] Sudikno Mertokusumo, 2003, Mengenal Hukum, Liberty, Yogyakarta

[2] Barda Nawawi Arief, 2008, Bunga Rampai Kebijakan Hukum Pidana, Prenada Media Group, Jakarta

[3] Mudzakir, 2012, Perencanaan Pembangunan Hukum Nasional Bidang Politik Hukum Pidana Dan Sistem Pemidanaan, Badan Pembinaan Hukum Nasional Kementrian Hukum Dan HAM Republik Indonesia, Jakarta

[4] Fatahillah A.Syukur, 2011, Mediasi Perkara KDRT teori dan Praktek Di Pengadilan Indonesia, Mandar Maju, Bandung, Bandung,

[5] Mukti Fajar ND dan Yulianto Achmad, 2010.Dualisme Penelitian Hukum Normatif \& Empiris, Pustaka Pelajar, Yogyakarta

[6] Burhan Bungin, 2001.Metode Penelitian Sosial, Format-format Kuantitatif dan Kualitatif.: Airlangga Unversity Press, Surabaya

[7] Nazir, Moh Metode Penelitian. Bogor: Ghalia Indonesia. 2013

[8] Suryono Ekotama, ST. Harum Pudjianto, dan G.Wiratana, Abortus Provocatus Bagi Korban Pemerkosaan Perspektif Viktimologi, Kriminologi dan Hukum Pidana ed. I; Universitas Atmajaya, Yogyakarta: 2001

\section{Legislation}

[1] Constitution of the Republic of Indonesia 1945 
[2] The Code of Criminal Procedure

[3] Act No. 23 of 2004, concerning the Elimination of Domestic Violence

[4] Act No. 31 of 2014 on the Protection of Witnesses and Victims

\section{Article}

[1] https://elisatris.wordpress.com/Peran Polri Dalam Perlindungan Anak Dan Penanggulangan Kekerasan Dalam Rumah Tangga. Accessed at 11 Nopember 2018. 